\title{
Cu AND Co EXCHANGED ZSM-5 ZEOLITES - ACTIVITY TOWARDS NO REDUCTION AND HYDROCARBON OXIDATION
}

Leandro Martins, Robson Pablo Sobradiel Peguin e Ernesto Antonio Urquieta-González*

Departamento de Engenharia Química, Universidade Federal de São Carlos, CP 676, 13560-970 São Carlos - SP

Recebido em 4/1/05; aceito em 29/6/05; publicado na web em 20/1/06

\begin{abstract}
$\left|\mathrm{Cu}_{\mathrm{x}}\right|\left[\mathrm{Si}_{\mathrm{y}} \mathrm{Al}\right]-\mathrm{MFI}$ and $\left|\mathrm{Co}_{\mathrm{x}}\right|\left[\mathrm{Si}_{\mathrm{y}} \mathrm{Al}\right]-\mathrm{MFI}$ catalysts were prepared by ion exchange from $|\mathrm{Na}|\left[\mathrm{Si}_{\mathrm{y}} \mathrm{Al}\right]-\mathrm{MFI}$ zeolites $(\mathrm{y}=12,25$ and 45). The activity of the catalysts was evaluated in the reduction of $\mathrm{NO}$ to $\mathrm{N}_{2}$ in an oxidative atmosphere using propane or methane as reducing agents. The $\mathrm{Cu}$ catalysts were only active with propane and they presented higher activity than the Co-based catalysts, the latter being active with both hydrocarbons. $\mathrm{H}_{2}$-TPR and DRS-UV/Vis data allowed correlation between the activity towards NO reduction and the presence of cationic charge-compensating species in the zeolite. It was also verified that the hydrocarbons are preferentially oxidised by $\mathrm{O}_{2}$, a reaction that occurs simultaneously with their oxidation with NO.
\end{abstract}

Keywords: $\left|\mathrm{Cu}_{\mathrm{x}}\right|\left[\mathrm{Si}_{\mathrm{y}} \mathrm{Al}\right]-\mathrm{MFI},\left|\mathrm{Co}_{\mathrm{x}}\right|\left[\mathrm{Si}_{\mathrm{y}} \mathrm{Al}\right]-\mathrm{MFI}$; NO reduction; propane oxidation.

\section{INTRODUCTION}

Environmental laws, which regulate the level of emission of nitrogen oxides $\left(\mathrm{NO}_{\mathrm{x}}\right)$ and other primary pollutants into the atmosphere, are becoming more restrictive. Thus, a large number of studies that aim to improve the catalytic conversion of $\mathrm{NO}_{x}$ to $\mathrm{N}_{2}$ by decomposition or reduction are being performed ${ }^{1,2}$. Special attention has been given to the selective catalytic reduction of NO with hydrocarbons (SCR-HC) under oxidative conditions, which is a potential solution for the treatment of exhaust gases that are generated by diesel engines or other combustion processes ${ }^{3}$.

In such processes the use of transition metal exchanged zeolites, as selective catalysts, has been proposed. Since the initial study by Iwamoto and $\mathrm{Hamada}^{4}$, which demonstrated that $\mathrm{Cu}$ exchanged ZSM$5\left(\left|\mathrm{Cu}_{x}\right|[\mathrm{Si} \mathrm{Al}]-\mathrm{MFI}\right)$ are active catalysts for the SCR-HC, several types of this catalyst have been intensively studied. The possible species present in $\left|\mathrm{Cu}_{\mathrm{x}}\right|\left[\mathrm{Si}_{\mathrm{y}} \mathrm{Al}\right]-\mathrm{MFI}$ type catalysts, generally identified by FTIR, $\mathrm{H}_{2}$-TPR, EPR or EXAFS, are copper cations $\left(\mathrm{Cu}^{2+}\right)$, oxocations $(\mathrm{Cu}-\mathrm{O}-\mathrm{Cu})^{2+}$ or copper oxide $(\mathrm{CuO})^{5}$. The presence of one particular species in the metal-exchanged zeolite depends on the exchanged metal content, on the $\mathrm{pH}$ value used during the ion exchange and on the atmosphere used during the subsequent thermal treatment. According to Gómez et al. ${ }^{6}$, the cationic species $\mathrm{Cu}^{2+}$ and $\mathrm{Cu}^{+}$in $\mathrm{Cu}$-catalysts have an important role in the catalytic reduction of $\mathrm{NO}_{\mathrm{x}}$ by hydrocarbons. Although these $\mathrm{Cu}$ based zeolitic catalysts show high activity for the SCR-HC from 400 to $800^{\circ} \mathrm{C}$, they deactivate rapidly in an atmosphere which contains excess of water and/or sulphur oxides ${ }^{7}$. On the other hand, in contrast to $\mathrm{Cu}$-based catalysts, zeolites containing Co-species have been demonstrated to be more promising due to their better catalytic performance under hydrothermal conditions ${ }^{8}$.

In addition to the deactivation by water vapour of $\mathrm{Cu}$ and $\mathrm{Co}-$ exchanged ZSM-5 zeolites during the SCR-HC, it has also been pointed out that preferential direct hydrocarbon oxidation by $\mathrm{O}_{2}$ rather than the desired reaction with $\mathrm{NO}$ can occur ${ }^{2}$, such behaviour limiting their activity towards the SCR-HC and more intensely at temperatures higher than $450{ }^{\circ} \mathrm{C}$ (Table 1 , reactions 2 and 4$)^{9}$. Although some water is formed in these reactions (lower than

*e-mail: urquieta@power.ufscar.br
Table 1. Main reactions occurring during the SCR-HC

\begin{tabular}{ccc}
\hline Number & Reaction & $-\Delta \mathrm{G}_{298} * / \mathrm{Kcal} \mathrm{mol}^{-1}$ \\
\hline 1 & $2 \mathrm{NO}+\mathrm{C}_{3} \mathrm{H}_{8}+4 \mathrm{O}_{2} \rightarrow \mathrm{N}_{2}+3 \mathrm{CO}_{2}+4 \mathrm{H}_{2} \mathrm{O}$ & 536.4 \\
2 & $\mathrm{CH}_{3}+5 \mathrm{O}_{2} \rightarrow 3 \mathrm{CO}_{2}+4 \mathrm{H}_{2} \mathrm{O}$ & 495.0 \\
3 & $2 \mathrm{NO}+\mathrm{CH}_{4}+\mathrm{O}_{2} \rightarrow \mathrm{N}_{2}+\mathrm{CO}_{2}+2 \mathrm{H}_{2} \mathrm{O}$ & 232.6 \\
4 & $\mathrm{CH}_{4}+2 \mathrm{O}_{2} \rightarrow \mathrm{CO}_{2}+2 \mathrm{H}_{2} \mathrm{O}$ & 191.3 \\
\hline
\end{tabular}

*Estimated from data available in reference 10.

$0.6 \%, \mathrm{v} / \mathrm{v})$, the amount present is not plausible to cause appreciable deactivation? ${ }^{7}$.

In the discussed field, the present study aims to verify the activity of $\left|\mathrm{Cu}_{\mathrm{x}}\right|$ and $\left|\mathrm{Co}_{\mathrm{x}}\right|\left[\mathrm{Si}_{\mathrm{y}} \mathrm{Al}\right]-\mathrm{MFI}$ catalysts in the NO reduction, using methane or propane as reducing agents, and for the simultaneous hydrocarbon oxidation with $\mathrm{O}_{2}$. The results obtained will be related to the metallic species formed during the preparation and activation of the catalysts.

\section{EXPERIMENTAL PART}

\section{Preparation of the catalysts}

The precursor $|\mathrm{Na}|\left[\mathrm{Si}_{\mathrm{y}} \mathrm{Al}\right]-\mathrm{MFI}$ zeolites (where $\mathrm{y}=12,25$, and 45 represent the $\mathrm{Si} / \mathrm{Al}$ ratio in the solid and MFI the ZSM-5 structure $)^{11,12}$ were synthesised as described elsewhere ${ }^{13}$. The synthesis was achieved using $n$-butylamine $\left(\mathrm{C}_{4} \mathrm{H}_{9} \mathrm{NH}_{2} 98 \%\right.$, Riedelde-Häen) as organic template and sodium trisilicate $\left(\mathrm{Na}_{2} \mathrm{Si}_{3} \mathrm{O}_{7} \times \mathrm{H}_{2} \mathrm{O}\right.$ $99 \%$, Aldrich) and aluminium sulphate hydrate $\left(\mathrm{Al}_{2} \mathrm{SO}_{4} \times 14-18 \mathrm{H}_{2} \mathrm{O}\right.$ $99 \%$, Reagen) as silica and aluminium sources, respectively. The zeolites were crystallised under autogenous pressure in static conditions at $170{ }^{\circ} \mathrm{C}$. After the synthesis, the $n$-butylamine occluded in the microporous of the zeolite was removed by calcination at $520^{\circ} \mathrm{C}$ for $16 \mathrm{~h}$, using a heating rate of $1^{\circ} \mathrm{C} \mathrm{min}-1$ and an air flow of $40 \mathrm{~mL} \mathrm{~min}^{-1} \mathrm{~g}_{\text {catalyst }}{ }^{-1}$. The $\left|\mathrm{Cu}_{\mathrm{x}}\right|$ and $\left|\mathrm{Co}_{\mathrm{x}}\right|\left[\mathrm{Si}_{\mathrm{y}} \mathrm{Al}\right]-\mathrm{MFI}$ catalysts (where $\mathrm{x}$ represents the metal/aluminium ratio) were obtained from the precursor $|\mathrm{Na}|$-zeolite by ion exchange in aqueous solutions of 0.015 mol L ${ }^{-1}$ of copper (II) acetate $\left(\mathrm{Cu}\left(\mathrm{O}-\mathrm{CO}-\mathrm{CH}_{3}\right)_{2} 99 \%\right.$, Merck) or of cobalt (II) acetate $\left(\mathrm{Co}\left(\mathrm{O}-\mathrm{CO}-\mathrm{CH}_{3}\right)_{2} 99 \%\right.$, Carlo Erba), respectively. A metal/Al ratio of 1.3 was employed and in order to obtain samples 
with different $\mathrm{Cu}$ and $\mathrm{Co}$ contents, the ion exchanges were carried out varying the temperature, the time and the number of exchanges. After each ion exchange, the solids were separated by filtration, washed with deionised water, dried at $110{ }^{\circ} \mathrm{C}$ for $12 \mathrm{~h}$ and subsequently activated by heating under air flow at $520^{\circ} \mathrm{C}$ for $1 \mathrm{~h}$, using a heating rate of $10^{\circ} \mathrm{C} \mathrm{min}^{-1}$.

\section{Characterisation}

In order to analyse the catalysts with similar chemical characteristics, all samples, prior to be submitted to the different characterisation techniques, they were activated as described above.

The $\mathrm{Si} / \mathrm{Al}$ ratio of the precursor $|\mathrm{Na}|\left[\mathrm{Si}_{\mathrm{y}} \mathrm{Al}\right]-\mathrm{MFI}$ zeolites was determined using atomic absorption spectroscopy (AAS) and the MFI structure was verified by powder X-ray diffraction (XRD), using a Rigaku Miniflex diffractometer operated with a $\mathrm{Cu}-\mathrm{K}_{\alpha}$ radiation and with a goniometer velocity of $2^{\circ}(2 \Theta) / \mathrm{min}$. The morphology of the crystals (size and shape) were determined by scanning electron microscopy (SEM) using a Zeiss DSM 960 microscope operated at $30 \mathrm{kV}$ and with a focus distance between 9 and $14 \mathrm{~mm}$.

The ${ }^{27} \mathrm{Al}$ MAS NMR spectra of the precursor $|\mathrm{Na}|\left[\mathrm{Si}_{\mathrm{y}} \mathrm{Al}\right]-\mathrm{MFI}$ zeolites were obtained on a Varian Unity $400 \mathrm{MHz}$ spectrometer, which worked with a frequency of 104.2 MHz. Aiming to excite only the central transition of the ${ }^{27} \mathrm{Al}$ nuclei, $\pi / 16$ pulses of $0.4 \mathrm{~ms}$ and repetition times of $2 \mathrm{~s}$ were used.

The temperature programmed reduction by hydrogen $\left(\mathrm{TPR}-\mathrm{H}_{2}\right)$ of $\mathrm{Cu}$ - and Co-catalysts was carried out using a Micromeritics 2705 equipment having a thermal conductivity detector. It was used a heating rate of $10{ }^{\circ} \mathrm{C} \mathrm{min}^{-1}$ and a mixture of $5.1 \%$ of $\mathrm{H}_{2}$ in $\mathrm{N}_{2}(\mathrm{v} / \mathrm{v})$ fed at a flow rate of $30 \mathrm{~mL} \mathrm{~min}^{-1}$. An amount of $150 \mathrm{mg}$ of sample, previously dried at $110{ }^{\circ} \mathrm{C}$ for $12 \mathrm{~h}$ was used in the analysis. To avoid the influence of the physically adsorbed water in the analysis, the samples were previously treated at $200{ }^{\circ} \mathrm{C}$ for $1 \mathrm{~h}$ under air flow $\left(30 \mathrm{~mL} \mathrm{~min}^{-1}\right)$. The water produced during the $\mathrm{H}_{2}$-TPR was removed through a cold trap.

Raman spectra of Co-catalysts were obtained at room temperature using a radiation of $633 \mathrm{~nm}$ from a $\mathrm{Ne}$ ion laser that was equipped with a CCD detector. The equipment was operated with a spot size of $1 \mu \mathrm{m}$ in diameter and a potency that was varied from 70 to $175 \mu \mathrm{W}$.

The analysis in the UV/VIS region by diffuse reflectance spectroscopy (DRS) was also performed at room temperature with a Varian Cary 5G spectrometer utilising a Teflon sample holder, a quartz window and a Teflon reference standard. The data obtained were processed by applying the Schuster-Kubelka-Munk function $\mathrm{F}(\mathrm{R})$.

\section{Catalytic tests}

The activity of the $\left|\mathrm{Cu}_{\mathrm{x}}\right|$ and $\left|\mathrm{Co}_{\mathrm{x}}\right|\left[\mathrm{Si}_{\mathrm{y}} \mathrm{Al}\right]$-MFI catalysts was evaluated in the reduction of $\mathrm{NO}$ to $\mathrm{N}_{2}$, using methane or propane as reducing agents, in an oxidative atmosphere. To avoid the formation of hot spots, the catalytic tests were carried out using 50 $\mathrm{mg}$ of the catalyst mixed with $150 \mathrm{mg}$ of quartz. The gas mixture $\left(70 \mathrm{~mL} \mathrm{~min} \mathrm{~m}^{-1}\right.$ ) was composed of: $0.3 \% \mathrm{NO}, 1.8 \% \mathrm{O}_{2}, 0.3 \% \mathrm{C}_{3} \mathrm{H}_{8}$ (or $0.3 \% \mathrm{CH}_{4}$ ) in $\mathrm{He}(\mathrm{v} / \mathrm{v})$. These operational conditions resulted in a gas hourly space velocity (GHSV) of $42,000 \mathrm{~h}^{-1}$, calculated considering the total gas flow fed to the reactor. The reaction temperature was varied from 150 to $500{ }^{\circ} \mathrm{C}$.

The products were analysed using a gas chromatograph (Shimadzu-GC-17A) equipped with a flame ionisation detector (FID), a thermal conductivity detector (TCD) and three columns: a capillary $\left(\mathrm{Al}_{2} \mathrm{O}_{3} / \mathrm{KCl}, 30 \mathrm{~m} \times 0.32 \mathrm{~mm}\right)$ and two packed columns (Hayesep D $\left(3 \mathrm{~m} \times 1 / 8^{\prime \prime}\right)$ and Chromossorb $\left.102\left(5 \mathrm{~m} \times 1 / 8^{\prime \prime}\right)\right)$.

The carbon balance was monitored during the reaction and the activity of the catalysts for the hydrocarbon oxidation was expressed in terms of the total hydrocarbon conversion. The conversion of NO $\left(\mathrm{X}_{\mathrm{NO}}\right)$ was based on the formation of $\mathrm{N}_{2}$ according to the equation: $\mathrm{X}_{\mathrm{NO}}[\%]=2\left[\mathrm{~N}_{2}\right] \times 100 /[\mathrm{NO}]_{0}$, where $\left[\mathrm{N}_{2}\right]=$ moles of $\mathrm{N}_{2}$ formed and $[\mathrm{NO}]_{\mathrm{o}}=$ moles of $\mathrm{NO}$ fed into the reactor.

\section{RESULTS AND DISCUSSION}

\section{Precursor characterisation}

The XRD patterns of the synthesised $|\mathrm{Na}|\left[\mathrm{Si}_{\mathrm{y}} \mathrm{Al}\right]-\mathrm{MFI}$ zeolites (Figure 1) reveal the presence of the MFI structure that is typical for ZSM-5 zeolites ${ }^{12}$. From Figure 1 it can also be observed for sample $|\mathrm{Na}|\left[\mathrm{Si}_{45} \mathrm{Al}\right]-\mathrm{MFI}$, the presence of a low intensity peak at $26.64^{\circ}(2 \Theta)$. This peak corresponds to the reflections related to the $\alpha$-quartz (101) atomic plane $\mathrm{e}^{12}$.

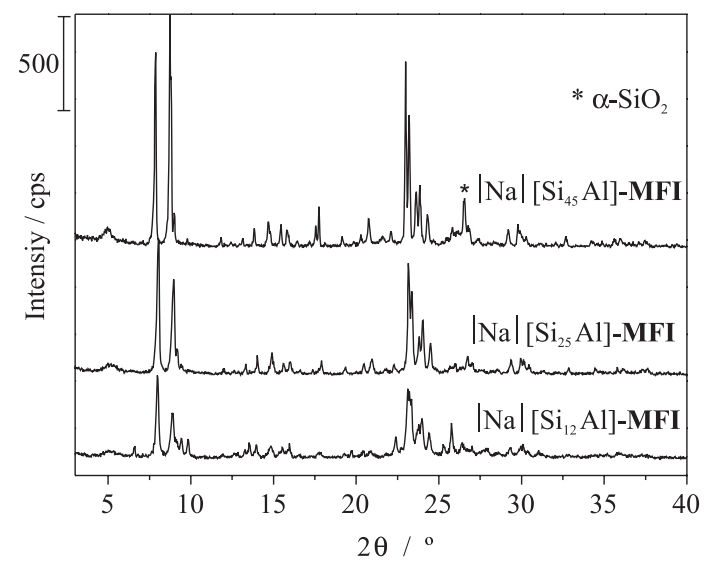

Figure 1. X-ray diffraction patterns of the activated $|\mathrm{Na}|\left[\mathrm{Si}_{y} \mathrm{Al}\right]-\mathrm{MFI}$ zeolites

The Si/Al ratios used in the synthesis gel and those corresponding to the obtained $|\mathrm{Na}|\left[\mathrm{Si}_{\mathrm{y}} \mathrm{Al}\right]-\mathrm{MFI}$ are shown in Table 2. The crystallinity of the samples (Table 2) was calculated from the XRD data (Equation 1) using the $|\mathrm{Na}|\left[\mathrm{Si}_{45} \mathrm{Al}\right]-\mathrm{MFI}$ sample as reference (crystallinity $=100 \%$ ), since it presented the XRD pattern with the highest peak intensity in the range $22^{\circ} \leq 2 \Theta \leq 25^{\circ}$.

$X-$ ray cristallinity $/ \%=\left(\frac{\sum A_{\text {peaks }}\left(22-25^{\circ}\right)_{\text {sample }}}{\sum A_{\text {peaks }}\left(22-25^{\circ}\right)_{\text {standard }}}\right) \cdot 100$

Although the crystallinities of the $|\mathrm{Na}|\left[\mathrm{Si}_{12} \mathrm{Al}\right]-\mathrm{MFI}$ and $|\mathrm{Na}|\left[\mathrm{Si}_{25} \mathrm{Al}\right]$-MFI samples were lower than that of sample $|\mathrm{Na}|\left[\mathrm{Si}_{45} \mathrm{Al}\right]-\mathrm{MFI}$, neither the XRD patterns nor the SEM micrographs (Figure 2) indicate the presence of amorphous material or other phases. At this point, the reduced intensity of the $\mathrm{X}$ ray reflections may be attributed to the smaller crystal size of these zeolites (see Figures $2 \mathrm{a}$ and $2 \mathrm{~b}$ ).

From data given in Table 2 it can be seen that the $\mathrm{Si} / \mathrm{Al}$ ratios of the synthesised zeolites were lower than those of the correspondent synthesis gels, indicating that aluminium is preferentially incorporated in the zeolite structure ${ }^{14}$, and subsequently part of the silica remains as sodium silicate in the liquid phase of the reaction mixture.

Figure 2 shows the $\mathrm{SEM}$ micrographs of the $|\mathrm{Na}|\left[\mathrm{Si}_{\mathrm{y}} \mathrm{Al}\right]-\mathrm{MFI}$ zeolites. It can be seen that the aluminium rich zeolite $|\mathrm{Na}|\left[\mathrm{Si}_{12} \mathrm{Al}\right]-$ MFI (Figure 2a) crystallises foring agglomerates (ca. $15 \mu \mathrm{m}$ ) of small crystals (ca. $3 \mu \mathrm{m}$ or lower). With the decrease in aluminium content, isolated or twinned hexagonal prisms are formed with dimensions of approximately 20 and $60 \mu \mathrm{m}$, as can be seen in the 
Table 2. Crystallinity and $\mathrm{Si} / \mathrm{Al}$ molar ratio in the synthesis gels and in the synthesised zeolites

\begin{tabular}{lccc}
\hline Sample & X-ray crystallinity $(\%)$ & $\mathrm{Si} / \mathrm{Al}_{\text {reaction gel }}$ & $\mathrm{Si} / \mathrm{Al}_{\text {solid }}$ \\
\hline$|\mathrm{Na}|\left[\mathrm{Si}_{12} \mathrm{Al}\right]-\mathrm{MFI}$ & 80 & 15 & 12 \\
$|\mathrm{Na}|\left[\mathrm{Si}_{25} \mathrm{Al}\right]-\mathrm{MFI}$ & 88 & 30 & 25 \\
$|\mathrm{Na}|\left[\mathrm{Si}_{45} \mathrm{Al}\right]-\mathrm{MFI}$ & 100 & 60 & 45 \\
\hline
\end{tabular}

a)

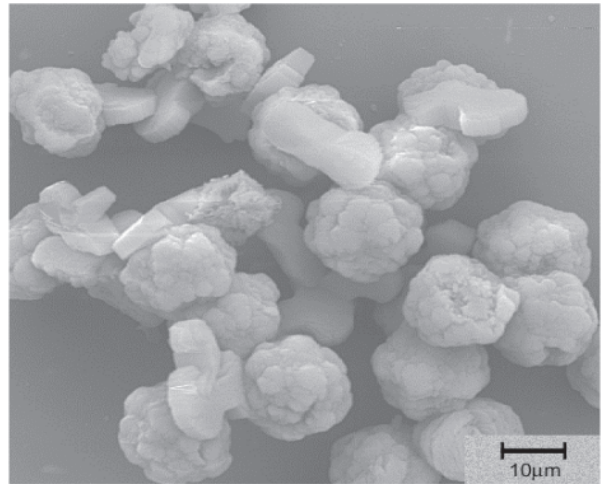

b)

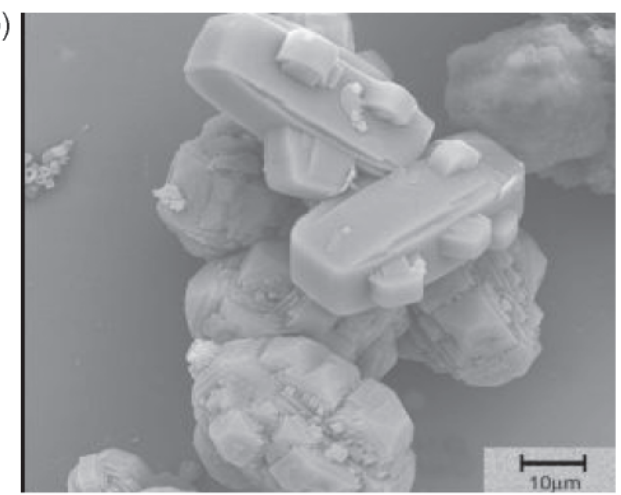

c)

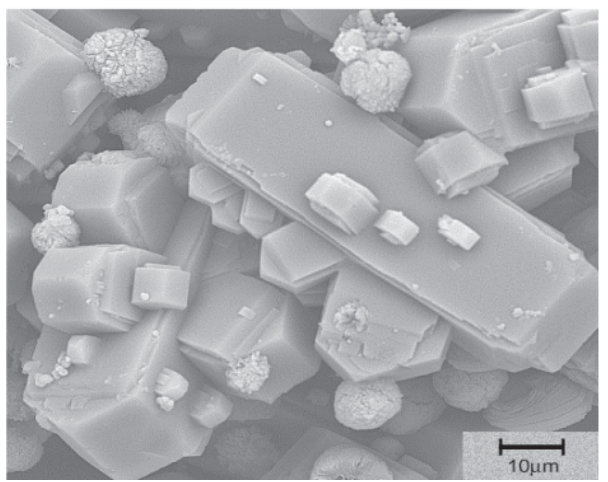

Figure 2. SEM micrographs of the activated: (a) $|\mathrm{Na}|\left[\mathrm{Si}_{12} \mathrm{Al}\right]-\mathbf{M F I},(b)$ |Na|[Si ${ }_{25}$ Al]-MFI and (c) $|\mathrm{Na}|\left[\mathrm{Si}_{45} \mathrm{Al}\right]-\mathbf{M F I}$

case of $|\mathrm{Na}|\left[\mathrm{Si}_{25} \mathrm{Al}\right]-\mathbf{M F I}$ and $|\mathrm{Na}|\left[\mathrm{Si}_{45} \mathrm{Al}\right]-\mathbf{M F I}$, respectively (Figures $2 \mathrm{~b}$ and $2 \mathrm{c}$ ). As mentioned above, no amorphous material was observed in the SEM micrographs of the $|\mathrm{Na}|\left[\mathrm{Si}_{12} \mathrm{Al}\right]-\mathrm{MFI}$ and $|\mathrm{Na}|\left[\mathrm{Si}_{25} \mathrm{Al}\right]-\mathrm{MFI}$ (Figures $2 \mathrm{a}$ and $2 \mathrm{~b}$ ). On the other hand, Figure $2 \mathrm{c}$ shows for $|\mathrm{Na}|\left[\mathrm{Si}_{45} \mathrm{Al}\right]-\mathrm{MFI}$ the presence of small particles $(<1 \mu \mathrm{m})$, other than the zeolite crystals. These small particles are probably crystals of $\alpha$-quartz, which was detected by XRD (Figure 1).

${ }^{27} \mathrm{Al}$ MAS NMR spectra of the $|\mathrm{Na}|\left[\mathrm{Si}_{\mathrm{y}} \mathrm{Al}\right]-\mathrm{MFI}$ zeolites (Figure 3) show a resonance peak at around $53 \mathrm{ppm}$, which is attributed to tetrahedrally co-ordinated $\mathrm{Al}$ atoms that are incorporated into the zeolite framework. For the $|\mathrm{Na}|\left[\mathrm{Si}_{12} \mathrm{Al}\right]-\mathrm{MFI}$ and $|\mathrm{Na}|\left[\mathrm{Si}_{25} \mathrm{Al}\right]-\mathrm{MFI}$ zeolites an additional signal at $0 \mathrm{ppm}$ is observed, which increases with the increase in aluminium content. This signal is associated to the extra-framework octahedrally co-ordinated aluminium, whose phase was not observed by SEM, indicating that it is well dispersed on the external surface or in the micropores of the ZSM-5 crystals. In addition to the lower $|\mathrm{Na}|\left[\mathrm{Si}_{12} \mathrm{Al}\right]-\mathbf{M F I}$ and $|\mathrm{Na}|\left[\mathrm{Si}_{25} \mathrm{Al}\right]-\mathbf{M F I}$ crystal size above commented, the presence of extra-framework aluminium might also explain the lower crystallinity observed by XRD.

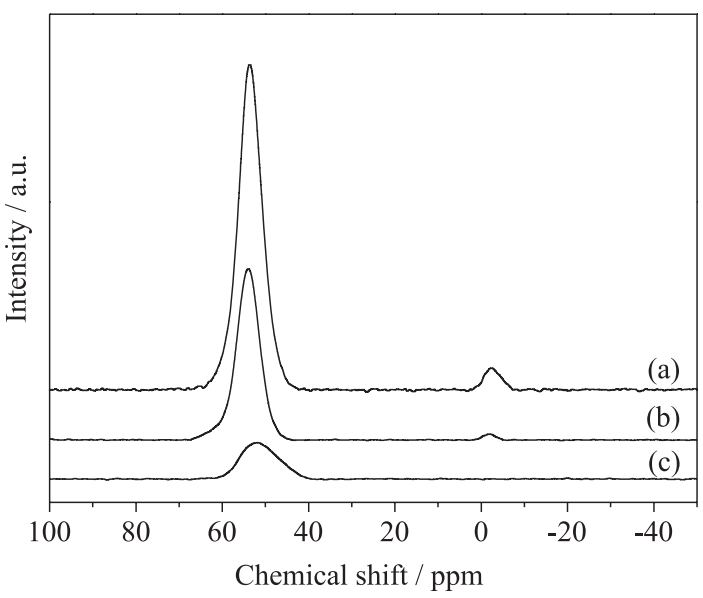

Figure 3. ${ }^{27} \mathrm{Al}$ MAS NMR spectra of the activated: (a) $|\mathrm{Na}|\left[\mathrm{Si}_{12} \mathrm{Al}\right]-\mathbf{M F I},(b)$ $|\mathrm{Na}|\left[\mathrm{Si}_{25} \mathrm{Al}\right]-\mathbf{M F I}$ and (c) $|\mathrm{Na}|\left[\mathrm{Si}_{45} \mathrm{Al}\right]-\mathbf{M F I}$

\section{Catalyst characterisation}

The elemental composition (Table 3) reveals that in the preparation of $\mathrm{Cu}$-catalysts, the copper content in the samples increases when the exchange temperature is increased from 25 to $50{ }^{\circ} \mathrm{C}$ or when the exchange is repeated. As can also be seen from Table 3, the same tendency is observed for Co-catalysts when the temperature was increased from 25 to $80^{\circ} \mathrm{C}$.

The TPR- $\mathrm{H}_{2}$ data for the $\mathrm{Cu}$ - and Co-containing catalysts is presented in Figure 4 and Figure 5, respectively, and the observed reduction temperatures and the ratio of consumed $\mathrm{H}_{2}$ per metal content are showed in Table 4.

As can clearly be observed in Figure 4 and from the data in Table 4 the reduction of $\left|\mathrm{Cu}_{x}\right|\left[\mathrm{Si}_{\mathrm{y}} \mathrm{Al}\right]-\mathrm{MFI}$ catalysts occurs in two well-defined steps, the two peaks having maximum at temperatures between 240 and $305{ }^{\circ} \mathrm{C}$ and between 420 and $600{ }^{\circ} \mathrm{C}$, respectively. Torre-Abreu et al..$^{15}$. attributed the low-temperature peak to the reduction of $\mathrm{Cu}^{2+}$ to $\mathrm{Cu}^{+}$and the peak at higher temperature to the reduction of $\mathrm{Cu}^{+}$to $\mathrm{Cu}^{0}$. After the TPR analysis, the presence of elemental copper was confirmed by the reddish colour of the samples. Figure 4 and Table 4 also reveal that irrespective of the $\mathrm{Si} / \mathrm{Al}$ ratio of the zeolite, the reduction temperatures of $\mathrm{Cu}^{2+}$ and $\mathrm{Cu}^{+}$increase as the copper content decreases. For samples with similar copper content, the reduction temperatures are higher for that with the highest $\mathrm{Si} / \mathrm{Al}$ ratio. This behaviour might be explained by the lower electronic density of samples with lower aluminium content, which makes the reduction of the metal difficult. Similar trends were observed by Sullivan and Cunningham ${ }^{16}$, who attributed such phenomena to an enhanced interaction between the cationic copper species and the zeolite structure. In the $\mathrm{TPR}-\mathrm{H}_{2}$ profiles of samples with higher $\mathrm{Cu}$ content, $\left|\mathrm{Cu}_{0.49}\right|\left[\mathrm{Si}_{12} \mathrm{Al}\right]-\mathbf{M F I}$ and $\left|\mathrm{Cu}_{0.30}\right|\left[\mathrm{Si}_{12} \mathrm{Al}\right]-\mathrm{MFI}$, can be observed a small shoulder at around $350{ }^{\circ} \mathrm{C}$ (indicated in Figure 4 with an arrow), which might be attributed to the reduction of finely dispersed $\mathrm{CuO}$ particles to elemental $\mathrm{Cu}^{017,18}$. As can be seen from Table 4, the sum of $\mathrm{H}_{2} / \mathrm{Me}$ ratio corresponding to peak 1 (A1) with the $\mathrm{H}_{2} / \mathrm{Me}$ ratio 
Table 3. Elemental composition of the prepared $\left|\mathrm{Cu}_{\mathrm{x}}\right|$ and $\left|\mathrm{Co}_{\mathrm{x}}\right|\left[\mathrm{Si}_{\mathrm{y}} \mathrm{Al}\right]-\mathrm{MFI}$ catalysts

\begin{tabular}{lcccc}
\hline Sample & Temperature $\left({ }^{\circ} \mathrm{C}\right)$ & Exchanges $\times$ Exchange time $(\mathrm{h})$ & Metal content $(\%$ w/w $)$ & Metal/Al \\
\hline$\left|\mathrm{Cu}_{0.49}\right|\left[\mathrm{Si}_{12} \mathrm{Al}\right]-\mathrm{MFI}$ & 25 & $3 \times 12$ & 4.00 & 0.49 \\
$\left|\mathrm{Cu}_{0.30}\right|\left[\mathrm{Si}_{12} \mathrm{Al}\right]-\mathrm{MFI}$ & 50 & $1 \times 12$ & 2.41 & 0.74 \\
$\left|\mathrm{Cu}_{0.18}\right|\left[\mathrm{Si}_{25} \mathrm{Al}\right]-\mathrm{MFI}$ & 25 & $2 \times 12$ & 0.34 & 0.30 \\
$\left|\mathrm{Cu}_{0.08}\right|\left[\mathrm{Si}_{25} \mathrm{Al}\right]-\mathrm{MFI}$ & 25 & $1 \times 12$ & 0.36 & 0.08 \\
$\left|\mathrm{Cu}_{0.16}\right|\left[\mathrm{Si}_{45} \mathrm{Al}\right]-\mathrm{MFI}$ & 25 & $2 \times 12$ & 2.17 & 0.16 \\
$\left|\mathrm{Co}_{0.29}\right|\left[\mathrm{Si}_{12} \mathrm{Al}\right]-\mathrm{MFI}$ & 80 & $1 \times 48$ & 4.80 & 0.29 \\
$\left|\mathrm{Co}_{0.58}\right|\left[\mathrm{Si}_{12} \mathrm{Al}\right]-\mathrm{MFI}$ & 80 & $3 \times 48$ & 0.59 & 0.58 \\
$\left|\mathrm{Co}_{0.15}\right|\left[\mathrm{Si}_{25} \mathrm{Al}\right]-\mathrm{MFI}$ & 80 & $1 \times 24$ & 1.36 & 0.15 \\
$\left|\mathrm{Co}_{0.36}\right|\left[\mathrm{Si}_{25} \mathrm{Al}\right]-\mathrm{MFI}$ & 80 & $1 \times 48$ & 0.05 & 0.36 \\
$\left|\mathrm{Co}_{0.01}\right|\left[\mathrm{Si}_{25} \mathrm{Al}\right]-\mathrm{MFI}$ & 25 & $1 \times 48$ & 0.01 \\
\hline
\end{tabular}

Table 4. $\mathrm{H}_{2}$ consumption and peak maximum observed in the TPR- $\mathrm{H}_{2}$ profiles of $\left|\mathrm{Cu}_{\mathrm{x}}\right|$ and $\left|\mathrm{Co}_{\mathrm{x}}\right|\left[\mathrm{Si} \mathrm{y}_{\mathrm{y}} \mathrm{Al}\right]-\mathrm{MFI}$ catalysts

\begin{tabular}{|c|c|c|c|c|c|c|c|}
\hline \multirow[t]{2}{*}{ Sample } & \multicolumn{3}{|c|}{ Peak Maximum $\left({ }^{\circ} \mathrm{C}\right)$} & \multirow[t]{2}{*}{$\mathrm{H}_{2} / \mathrm{Me}(\mathrm{A} 1)^{\mathrm{a}}$} & \multirow[t]{2}{*}{$\mathrm{H}_{2} / \mathrm{Me}(\mathrm{A} 2)^{\mathrm{a}}$} & \multirow[t]{2}{*}{$\mathrm{H}_{2} / \mathrm{Me}(\mathrm{A} 3)^{\mathrm{a}}$} & \multirow[t]{2}{*}{$\mathrm{H}_{2} / \mathrm{Me}$ Total $^{\mathrm{a}}$} \\
\hline & $1^{\text {st }}$ & $2^{\text {nd }}$ & $3^{\text {rd }}$ & & & & \\
\hline$\left|\mathrm{Cu}_{0.49}\right|\left[\mathrm{Si}_{12} \mathrm{Al}\right]-\mathrm{MFI}$ & 240 & 420 & - & 0.49 & 0.49 & - & 1.07 \\
\hline$\left|\mathrm{Cu}_{0.30}\right|\left[\mathrm{Si}_{12} \mathrm{Al}\right]-\mathrm{MFI}$ & 250 & 450 & - & 0.46 & 0.45 & - & 0.98 \\
\hline$\left|\mathrm{Cu}_{0.18}\right|\left[\mathrm{Si}_{25} \mathrm{Al}\right]-\mathrm{MFI}$ & 245 & 615 & - & 0.49 & 0.43 & - & 0.92 \\
\hline$\left|\mathrm{Cu}_{0.16}\right|\left[\mathrm{Si}_{25} \mathrm{Al}\right]-\mathrm{MFI}$ & 270 & 630 & - & 0.56 & 0.52 & - & 1.08 \\
\hline$\left|\mathrm{Cu}_{0.08}\right|\left[\mathrm{Si}_{45} \mathrm{Al}\right]-\mathrm{MFI}$ & 305 & 600 & - & 0.52 & 0.47 & - & 0.99 \\
\hline$\left|\mathrm{Co}_{0.58}\right|\left[\mathrm{Si}_{12} \mathrm{Al}\right]-\mathrm{MFI}$ & 320 & - & 750 & $0.10(0.06)^{b}$ & - & 1.22 & 1.32 \\
\hline$\left|\mathrm{Co}_{0.36}\right|\left[\mathrm{Si}_{25} \mathrm{Al}\right]-\mathrm{MFI}$ & - & - & 780 & - & - & 0.95 & 0.95 \\
\hline$\left|\mathrm{Co}_{0.29}\right|\left[\mathrm{Si}_{25} \mathrm{Al}\right]-\mathrm{MFI}$ & - & - & 770 & - & - & 1.15 & 1.15 \\
\hline
\end{tabular}

a moles of consumed $\mathrm{H}_{2} /$ moles of $\mathrm{Cu}^{2+}$ or $\mathrm{Co}^{2+} \cdot \mathbf{b}$ in brackets is indicated the ratio of consumed $\mathrm{H}_{2} / \mathrm{moles}_{\text {of }} \mathrm{Co}^{3+}$.

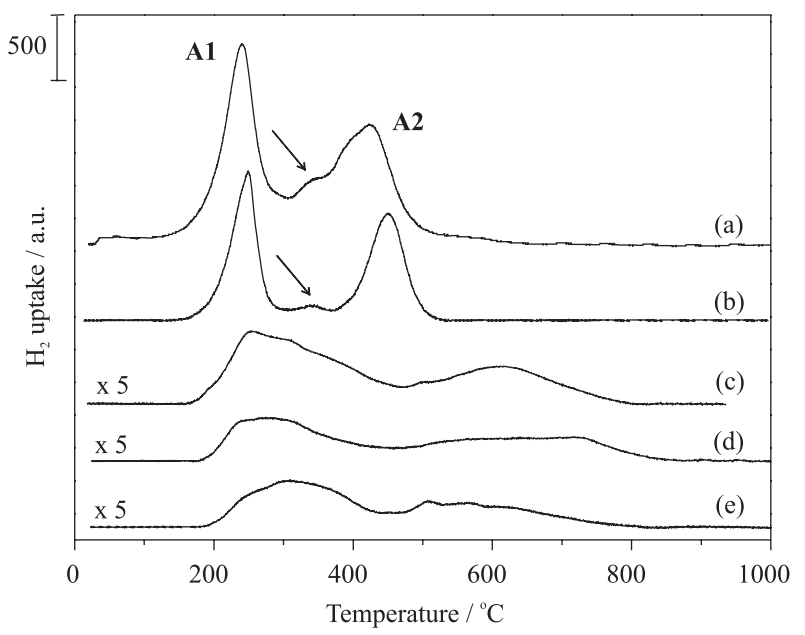

Figure 4. TPR- $\mathrm{H}_{2}$ profiles of the activated: (a) $\left|\mathrm{Cu}_{0.49}\right|\left[S i_{12} \mathrm{Al}\right]-\mathbf{M F I},(b)$ $\left|C u_{0.30}\right|\left[S i_{12} A l\right]-\mathbf{M F I},(c)\left|C u_{0.18}\right|\left[S i_{25} A l\right]-M F I,(d)\left|C u_{0.16}\right|\left[S i_{45} A l\right]-\mathbf{M F I}$ and $(e)$ $\left|\mathrm{Cu} u_{0.08}\right|\left[S i_{25} \mathrm{Al]}-\mathbf{M F I}\right.$

corresponding to peak 2 (A2) does not correspond to the total hydrogen consumption $\left(\mathrm{H}_{2} / \mathrm{Me}\right.$ total). This difference in the $\mathrm{H}_{2}$ consumption might be attributed to the presence of $\mathrm{CuO}$, whose content in each catalyst (show in Table 5) was estimated considering the stoichiometry of the $\mathrm{CuO}$ reduction: $\mathrm{CuO}+\mathrm{H}_{2} \rightarrow \mathrm{Cu}^{0}+\mathrm{H}_{2} \mathrm{O}$; resulting in 0.4 and $0.17 \% \mathrm{w} / \mathrm{w}$ for the $\left|\mathrm{Cu}_{0.49}\right|$ and $\left|\mathrm{Cu}_{0.30}\right|\left[\mathrm{Si}_{12} \mathrm{Al}\right]-$ MFI, respectively.

$\mathrm{CuO}$ can be formed during calcination from hydroxylated species generated during the ion exchange ${ }^{19}$, such as $\mathrm{Cu}^{\mathrm{n}+}(\mathrm{OH})_{n}$, $\mathrm{Cu}^{(\mathrm{n}+\mathrm{m})+}(\mathrm{OH})_{\mathrm{m}}\left(\mathrm{O}-\mathrm{CO}-\mathrm{CH}_{3}\right)_{\mathrm{n}}$ or $\mathrm{Cu}^{\mathrm{n}+}(\mathrm{OH})_{\mathrm{m}}{ }^{(\mathrm{n}-\mathrm{m})+}$, resulting in a $\mathrm{pH}$ decrease from 5.5 to 4.9 .

As can be seen from the TPR- $\mathrm{H}_{2}$ profiles of Figure 5, all the $\left|\mathrm{Co}_{\mathrm{x}}\right|\left[\mathrm{Si}_{\mathrm{y}} \mathrm{Al}\right]-\mathrm{MFI}$ catalysts show an intense reduction peak with maximum at temperatures between 660 and $720{ }^{\circ} \mathrm{C}$ (Table 4). Wang et $a{ }^{20}{ }^{20}$. and Cruz et al. ${ }^{21}$. attributed this peak to the reduction of $\mathrm{Co}^{2+}$ to $\mathrm{Co}^{\circ}$ in charge- compensating sites of the zeolite structure. For the $\left|\mathrm{Co}_{0.58}\right|\left[\mathrm{Si}_{12} \mathrm{Al}\right]-\mathrm{MFI}$ catalyst, which has the highest cobalt content, the low intensity reduction peak at around $320^{\circ} \mathrm{C}$, might be attributed to the reduction of cobalt oxide species. As in the case of $\mathrm{CuO}$, the $\mathrm{Co}_{3} \mathrm{O}_{4}$ content in the Co-catalysts (Table 5) was estimated from the stoichiometry of its reduction, using the consumed $\mathrm{H}_{2}$ (peak at $320{ }^{\circ} \mathrm{C}$ ), resulting for the $\left|\mathrm{Co}_{0.58}\right|\left[\mathrm{Si}_{12} \mathrm{Al}\right]-$ MFI in $0.7 \% \mathrm{w} / \mathrm{w}$. In the other samples this peak was not observed, probably due to their lower cobalt content. As in the case of $\mathrm{Cu}$ catalysts, the formation of cobalt oxides is also related to the formation of cobalt hydroxide species during ion exchange, where a $\mathrm{pH}$ decrease from 6.0 to 4.9 was observed.

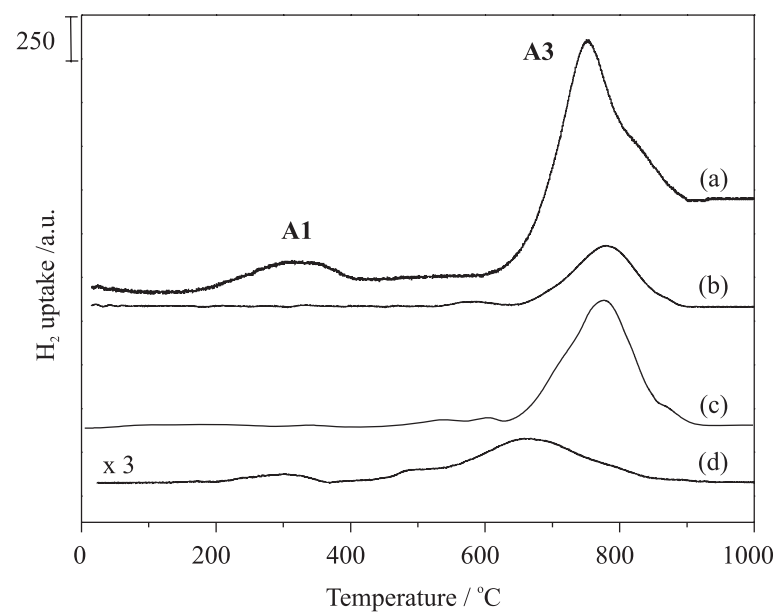

Figure 5. TPR- $\mathrm{H}_{2}$ profiles of the activated: (a) $\left|\mathrm{Co}_{0.58}\right|\left[\mathrm{Si}_{12} \mathrm{Al}\right]-\mathrm{MFI},(b)$ $\left|\mathrm{Co}_{0.36}\right|\left[\mathrm{Si}_{25} \mathrm{Al}\right]-\mathbf{M F I},(\mathrm{c})\left|\mathrm{Co}_{0.29}\right|\left[\mathrm{Si}_{12} \mathrm{Al}\right]-\mathbf{M F I}$ and $(d)\left|\mathrm{Co}_{0.15}\right|\left[\mathrm{Si}_{25} \mathrm{Al}\right]-\mathbf{M F I}$ 
As mentioned, Table 4 also presents the ratio of total consumed $\mathrm{H}_{2}$ per metal content for $\mathrm{Cu}$ and Co-catalysts. Theoretically, for each divalent metal cation $\left(\mathrm{Me}^{2+}\right)$ reduced to $\mathrm{Me}^{0}$ the $\mathrm{H}_{2} / \mathrm{Me}$ ratio should be equal to $1 . \mathrm{H}_{2} / \mathrm{Me}$ values below 1 could indicate incomplete reduction of the metal, while values higher than 1 could be related to the simultaneous reduction of species other than the $\mathrm{Me}^{2+}$ cations. For $\mathrm{Cu}$-catalysts no significant deviation from 1 is observed, indicating complete reduction of copper species. For the sample $\left|\mathrm{Co}_{0.58}\right|\left[\mathrm{Si}_{12} \mathrm{Al}\right]$-MFI a value of $\mathrm{H}_{2} / \mathrm{Me}$ equal to 1.32 was obtained, which can be explained by considering the simultaneous reduction of $\mathrm{Co}^{2+}$ and trivalent $\mathrm{Co}^{3+}$. The trivalent species are present due to the partial oxidation of $\mathrm{Co}^{2+}$ (present in $\mathrm{CoO}$ ) to give $\mathrm{Co}^{3+}$ and generating $\mathrm{Co}_{3} \mathrm{O}_{4}$. Similar observations were made by Wang et al. ${ }^{20}$ for cobalt-containing ZSM-5 zeolite.

In order to obtain further information about the Co-oxide species present in the Co-catalysts, Raman measurements were performed. Figure 6 shows the spectra obtained from the $\left|\mathrm{Co}_{0.58}\right|\left[\mathrm{Si}_{12} \mathrm{Al}\right]-\mathrm{MFI}$ catalyst, $\mathrm{Co}_{3} \mathrm{O}_{4}$ (reference sample) and the zeolite used as precursor. As can be seen, the bands at 303 and $385 \mathrm{~cm}^{-1}$ in the spectrum of $\left|\mathrm{Co}_{0.58}\right|\left[\mathrm{Si}_{12} \mathrm{Al}\right]$-MFI correspond to the zeolite framework and they are not related to the Co-species ${ }^{22}$. In addition, bands at 197, 483, 529, 616 and $692 \mathrm{~cm}^{-1}$ can be observed in the spectra. These bands are attributed to $\mathrm{Co}_{3} \mathrm{O}_{4}$ agglomerates, which must be smaller than $3 \mathrm{~nm}$, as they were not detected by XRD. In the same spectrum, a band at around 580 $\mathrm{cm}^{-1}$ is also observed. As this band can not be attributed to the zeolite framework nor to $\mathrm{Co}_{3} \mathrm{O}_{4}$, it is suggested that it corresponds to a loaded cobalt species other than $\mathrm{Co}_{3} \mathrm{O}_{4}(\text { e. g. } \mathrm{CoO}(\mathrm{OH}))^{22}$.

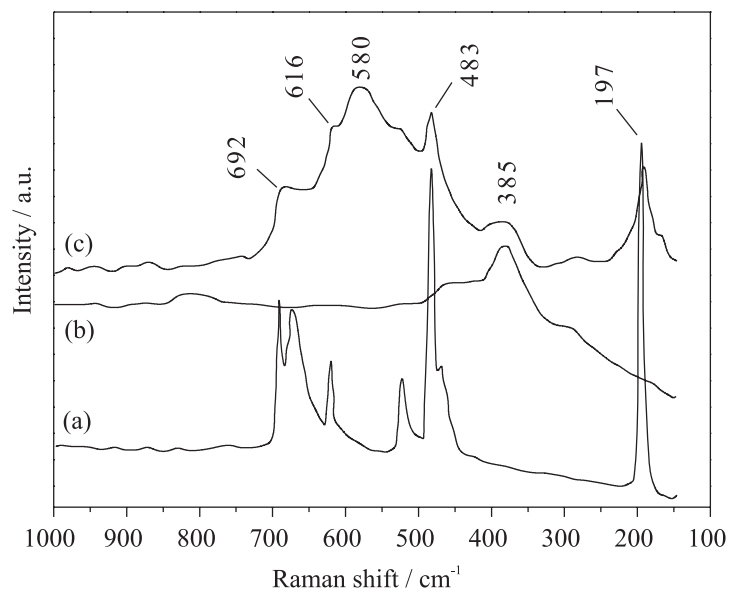

Figure 6. Raman spectra of the activated: (a) $\mathrm{Co}_{3} \mathrm{O}_{4},(b)\left|\mathrm{Na}_{x}\right|\left[\mathrm{Si}_{12} \mathrm{Al}\right]-\mathbf{M F I}$ and (c) $\left|\mathrm{Co}_{0.58}\right|\left[\mathrm{Si}_{12} \mathrm{Al}\right]-\mathbf{M F I}$

Figure 7 shows the DRS-UV/VIS spectra of the $\left|\mathrm{Cu}_{\mathrm{x}}\right|\left[\mathrm{Si}_{\mathrm{y}} \mathrm{Al}\right]-$ MFI catalysts. The presence of bands at around 212, 256 and a broad, but weak band between 600 and $850 \mathrm{~nm}$ can be observed. Itho et al..$^{23}$ reported that the band at $212 \mathrm{~nm}$, which appears in the spectra of all samples, is related to the zeolitic support and therefore not related to the $\mathrm{Cu}$-species. The band at $256 \mathrm{~nm}$ is attributed to $\mathrm{Cu}^{2+}$ interacting with oxygen atoms in the zeolite structure and the band between 600 and $850 \mathrm{~nm}$ to $\mathrm{Cu}^{2+}$ cations in hexagonal coordination (this band is indicated in Figure 7 between arrows $)^{23,24}$. Although the above discussed TPR- $\mathrm{H}_{2}$ results suggest the presence of small amounts of $\mathrm{CuO}$ in the $\left|\mathrm{Cu}_{\mathrm{x}}\right|\left[\mathrm{Si}_{\mathrm{y}} \mathrm{Al}\right]-\mathbf{M F I}$ catalysts, in their DRS-UV/VIS spectra there is no band at around $890 \mathrm{~nm}$, which could indicate the presence of this species ${ }^{25}$. This fact could be a consequence of the low concentration of $\mathrm{CuO}$ in the samples.

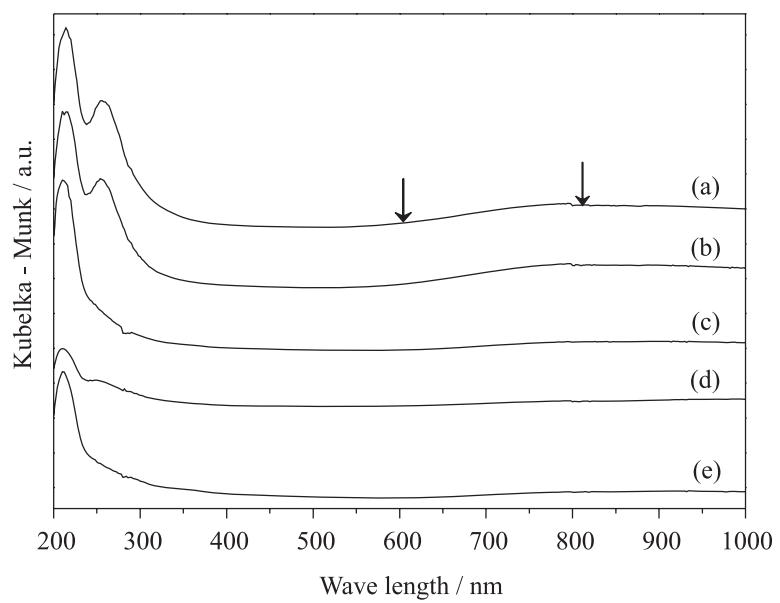

Figure 7. DRS-UV/Vis spectra of the activated: (a) $\left|\mathrm{Cu} u_{049}\right|\left[S i_{12} A l\right]-\mathbf{M F I}$, (b) $\left|\mathrm{Cu} u_{0.30}\right|\left[S i_{12} A l\right]-\mathbf{M F I},(c)\left|C u_{0.18}\right|\left[S i_{25} A l\right]-\mathbf{M F I},(d)\left|C u_{0.16}\right|\left[S i_{45} A l\right]-\mathbf{M F I}$ and (e) $\left|\mathrm{Cu} u_{0.08}\right|\left[S i_{25} \mathrm{Al}\right]-\mathbf{M F I}$

In the DRS-UV/VIS spectra of $\left|\mathrm{Co}_{\mathrm{x}}\right|\left[\mathrm{Si}_{\mathrm{y}} \mathrm{Al}\right]-\mathrm{MFI}$ catalysts bands at 210, 255 and between $415-600 \mathrm{~nm}$ can be observed (Figure 8). The latter, which is present only in samples with a high metal content, is attributed to $\mathrm{Co}_{3} \mathrm{O}_{4}$ oxide ${ }^{26}$. The bands at 210 and 255 $\mathrm{nm}$ are associated to the electronic transitions of the zeolite structure and to $\mathrm{Co}^{2+}$ species compensating the negative charge of the zeolite, respectively.

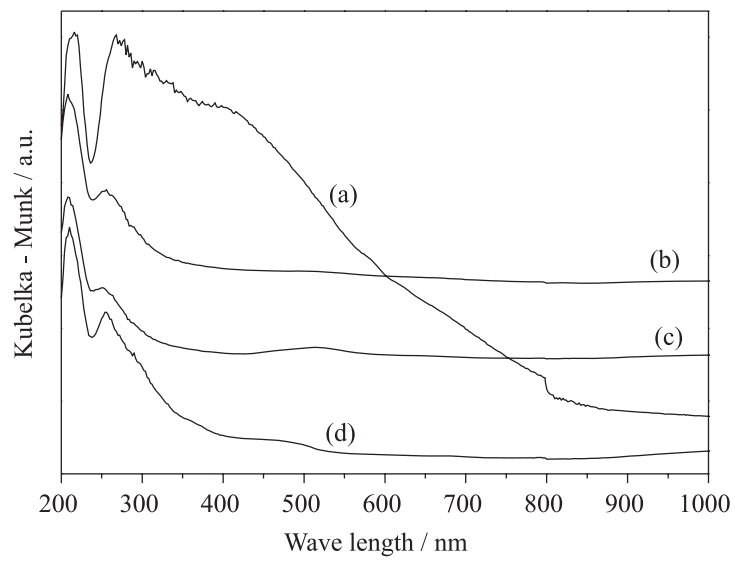

Figure 8. DRS-UV/Vis spectra of the activated: (a) $\left|\mathrm{Co}_{0.58}\right|\left[S i_{12} \mathrm{Al}\right]-\mathrm{MFI},(b)$ $\left|\mathrm{Co}_{0.36}\right|\left[S i_{25} \mathrm{All}\right]-\mathbf{M F I},(\mathrm{c})\left|\mathrm{Co} o_{0.29}\right|\left[\mathrm{Si}_{12} \mathrm{Al}\right]-\mathbf{M F I}$ and $(\mathrm{d})\left|\mathrm{Co}_{0.15}\right|\left[\mathrm{Si}_{25} \mathrm{Al}\right]-\mathbf{M F I}$

In the activated $\left|\mathrm{Co}_{0.58}\right|\left[\mathrm{Si}_{12} \mathrm{Al}\right]$-MFI sample, these bands are broader and more intense, particularly the band at $415-600 \mathrm{~nm}$. Therefore, in this catalyst, $\mathrm{Co}^{3+}$ species are probably present in a higher proportion, thus explaining its higher $\mathrm{H}_{2} / \mathrm{Co}$ ratio obtained in the TPR (see Table 4) and the $\mathrm{Co}_{3} \mathrm{O}_{4}$ bands detected by Raman spectroscopy.

\section{Catalytic evaluation}

In the following discussion about the activity of the $\mathrm{Cu}$ - and Co-catalysts, it was not considered the effect of water generated in the hydrocarbon oxidation. As mentioned, the amount of water formed (lower than $0.6 \% \mathrm{v} / \mathrm{v}$ ) is not plausible to cause appreciable deactivation ${ }^{7}$.

Figure 9a shows the conversion of $\mathrm{NO}$ to $\mathrm{N}_{2}$ on $\left|\mathrm{Cu}_{x}\right|\left[\mathrm{Si}_{\mathrm{y}} \mathrm{Al}\right]-$ MFI as a function of the reaction temperature, using propane or 
methane as reducing agent. It can be observed that the conversion of NO depends on the temperature, the type of hydrocarbon and the copper content.
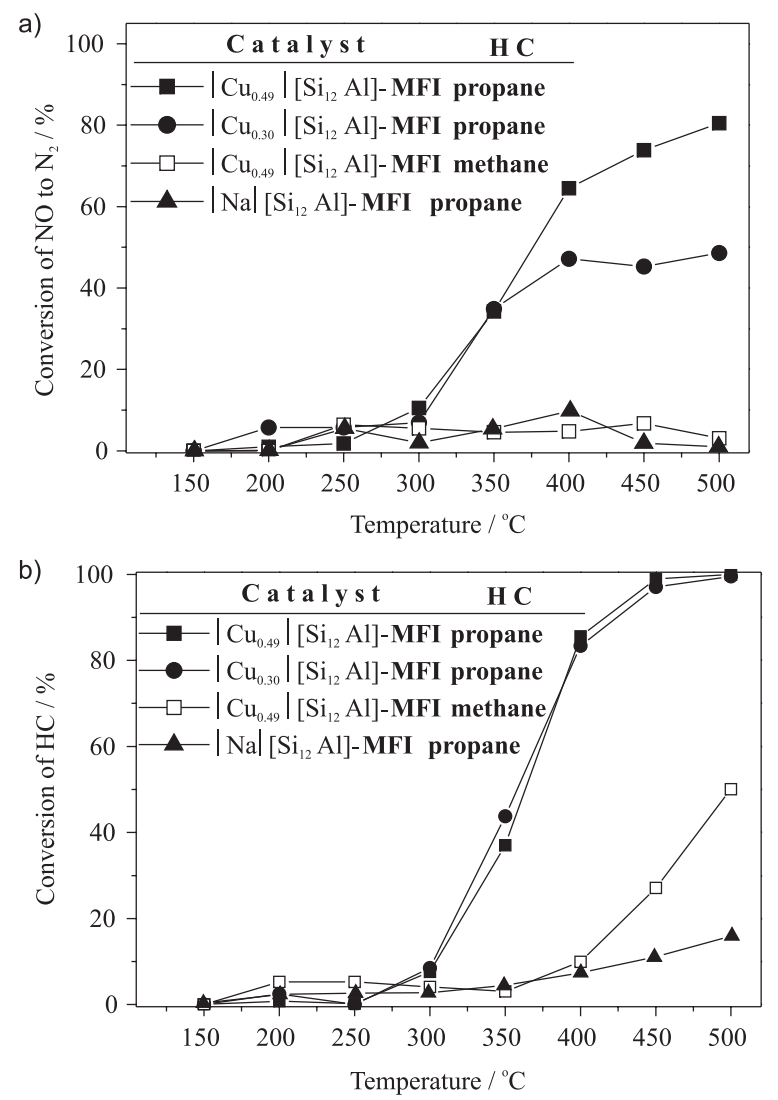

Figure 9. Conversion of: (a) $\mathrm{NO}$ to $\mathrm{N}_{2}$ and (b) hydrocarbon, as a function of the temperature for the activated $\left|\mathrm{Cu} u_{x}\right|\left[\mathrm{Si}_{y} \mathrm{Al}\right]-\mathrm{MFI}$ catalysts

The $\left|\mathrm{Cu}_{x}\right|\left[\mathrm{Si}_{12} \mathrm{Al}\right]-\mathrm{MFI}$ catalysts, in comparison with the precursor $|\mathrm{Na}|\left[\mathrm{Si}_{12} \mathrm{Al}\right]$-MFI zeolite (Figure 9), are active catalysts for the conversion of $\mathrm{NO}$ to $\mathrm{N}_{2}$ in the presence of propane and their activity increases as the copper content increases. For propane oxidation, the activity of the studied $\left|\mathrm{Cu}_{\mathrm{x}}\right|\left[\mathrm{Si}_{\mathrm{y}} \mathrm{Al}\right]-\mathrm{MFI}$ catalysts was not influenced by the metal content and it was only slightly modified in the presence or in the absence of NO (Figure 10). When NO was fed to the reactor, the propane conversion decreased

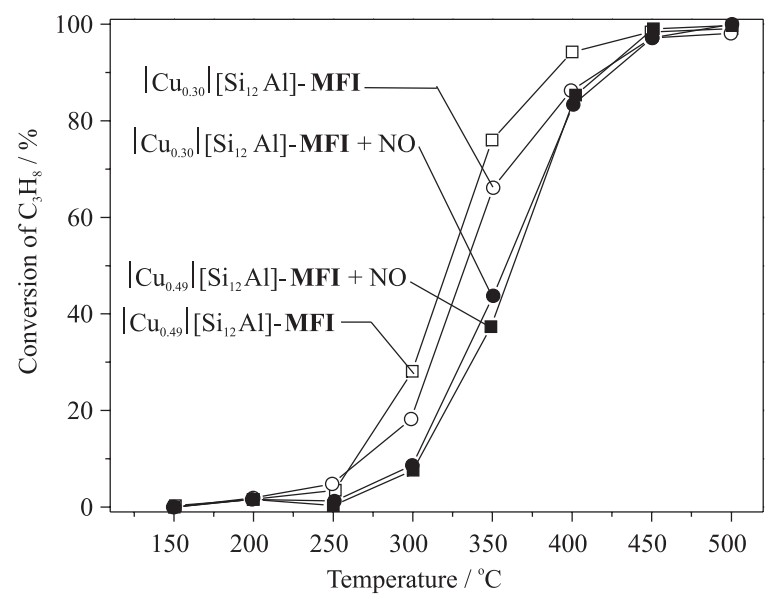

Figure 10. Propane oxidation on activated $\left|\mathrm{Cu}_{x}\right|\left[\mathrm{Si}_{12} \mathrm{Al}\right]-\mathrm{MFI}$ catalysts, in the presence or in the absence of $N O$ due to the competition between propane and NO for the active sites of the catalyst (Table 1, reactions 1 and 2). On the other hand, Figure 9 reveals that $\left|\mathrm{Cu}_{\mathrm{x}}\right|\left[\mathrm{Si}_{\mathrm{y}} \mathrm{Al}\right]-\mathrm{MFI}$ catalysts are not active in the reduction of $\mathrm{NO}$ in the presence of methane and also show low activity in the oxidation of this hydrocarbon. This behaviour was also observed by $\mathrm{Li}$ and $\mathrm{Armor}^{27}$ and it is probably related to the high energy necessary for the $\mathrm{C}-\mathrm{H}$ dissociation in methane, which is following Adelman et al. ${ }^{28}$, the limiting step in the reduction of NO by alkanes over copper-containing ZSM-5 zeolites. For the $\left|\mathrm{Cu}_{\mathrm{x}}\right|\left[\mathrm{Si}_{\mathrm{y}} \mathrm{Al}\right]-\mathrm{MFI}$ catalysts in the tests using propane, it can be seen that the conversion of NO increases more slightly at temperatures higher than $400{ }^{\circ} \mathrm{C}$. This behaviour is attributed to an increase in the desorption rate of $\mathrm{NO}$ at higher temperatures and to a decrease in the propane concentration, which is associated with the increase of its direct oxidation by $\mathrm{O}_{2}$ at those temperatures (Table 1, reaction 2).

Figure 11 shows that $\left|\mathrm{Co}_{\mathrm{x}}\right|\left[\mathrm{Si}_{\mathrm{y}} \mathrm{Al}\right]-\mathrm{MFI}$ catalysts have low activity for the reduction of $\mathrm{NO}$ to $\mathrm{N}_{2}$ in the presence of propane. On the other hand, in the presence of methane, which is also partially converted, $\left|\mathrm{Co}_{\mathrm{x}}\right|\left[\mathrm{Si}_{\mathrm{y}} \mathrm{Al}\right]-\mathrm{MFI}$ catalysts reduce in more extension $\mathrm{NO}$ to $\mathrm{N}_{2}$ (Table 1 , reaction 3), with the conversion increasing with the increase in the cobalt content in the catalyst. This behaviour, which differs from that obtained on $\left|\mathrm{Cu}_{\mathrm{x}}\right|\left[\mathrm{Si}_{\mathrm{y}} \mathrm{Al}\right]-\mathrm{MFI}$ catalysts using the same hydrocarbon, might be explained by the different intermediate nitrogen species formed on each catalyst. Adelman et al. ${ }^{28}$ found that in the presence of $\mathrm{NO}$ and $\mathrm{O}_{2}$, nitro and/or nitrate complexes $\left(\left[\mathrm{Cu}\left(\mathrm{NO}_{2}\right)_{\mathrm{y}}\right]^{2+}\right.$ or $\left.\mathrm{Cu}\left[\left(\mathrm{NO}_{3}\right)_{y}\right]^{(2-\mathrm{y})+}\right)$ are predominantly formed on $\left|\mathrm{Cu}_{\mathrm{x}}\right|\left[\mathrm{Si}_{\mathrm{y}} \mathrm{Al}\right]-\mathrm{MFI}$, while nitrite complexes $\left(\left[\mathrm{Co}(\mathrm{ONO})_{\mathrm{y}}\right]^{2+}\right)$ are predominant on $\left|\mathrm{Co}_{\mathrm{x}}\right|\left[\mathrm{Si}_{\mathrm{y}} \mathrm{Al}\right]-\mathrm{MFI}$ catalysts. The latter are reduced
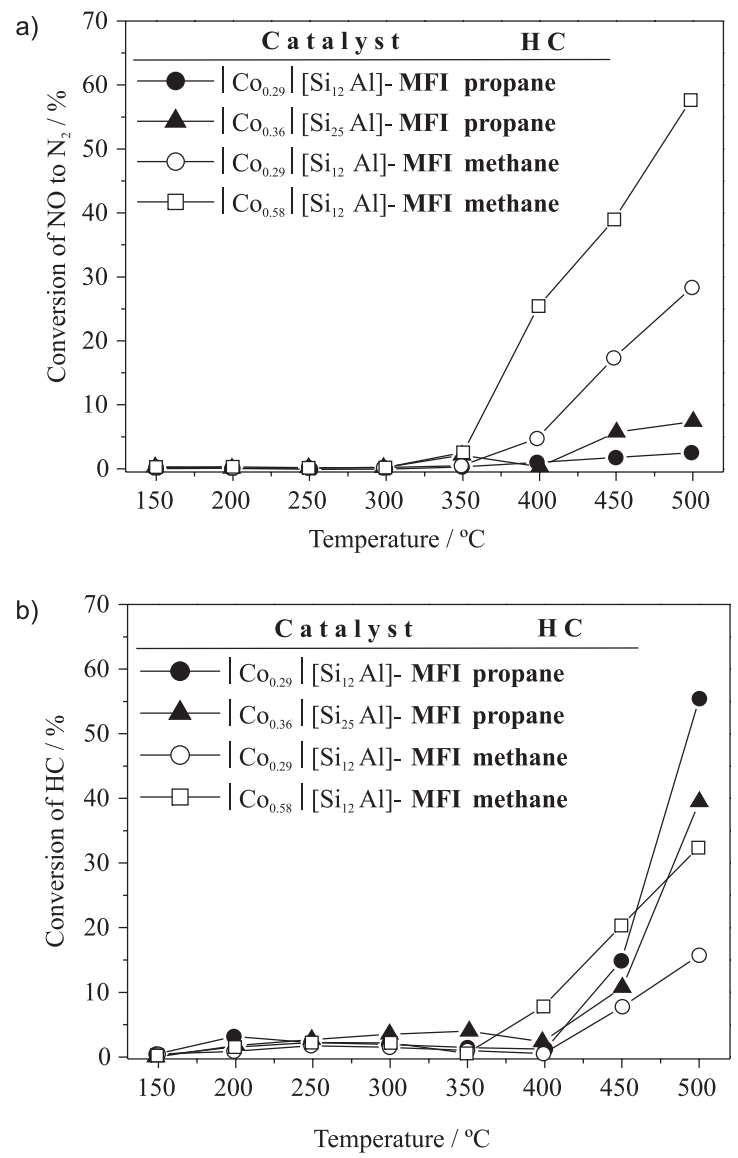

Figure 11. Conversion of: (a) $\mathrm{NO}$ to $\mathrm{N}_{2}$ and (b) hydrocarbon as function of the temperature for the activated $\mid$ Co $\left.\right|_{x}[$ SiA Al]-MFI catalysts 
upon exposure to $\mathrm{CH}_{4}$ leading to the formation of $\mathrm{N}_{2}$ and different methane oxidation products, while the nitro and/or nitrate complexes are chemically reduced to $\mathrm{N}_{2}$ upon exposure to $\mathrm{C}_{3} \mathrm{H}_{8}$ and remain inert in the presence of $\mathrm{CH}_{4}$.

Figure 12 shows the conversion of propane on $\left|\mathrm{Co}_{x}\right|\left[\mathrm{Si}_{\mathrm{y}} \mathrm{Al}\right]-\mathrm{MFI}$ catalysts with different cobalt contents. As can be observed, these catalysts show similar behaviour that was observed for the coppercontaining catalysts, in which the conversion of propane was decreased due to the competition between NO and propane for the active sites.

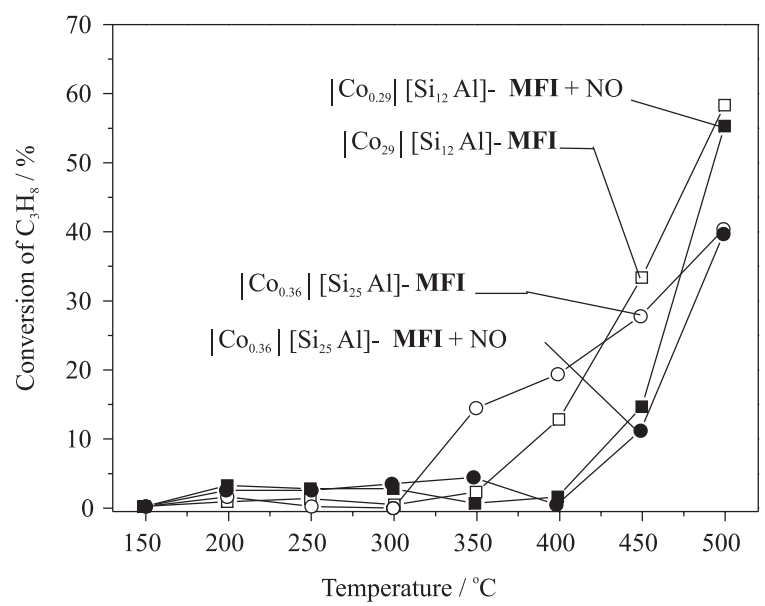

Figure 12. Propane oxidation on activated $\left|\mathrm{Co}_{x}\right|[\mathrm{Si}$ Al]-MFI catalysts, in the presence or in the absence of $\mathrm{NO}$

The analysis of the reaction products by gas chromatography demonstrated that the oxidation of propane on copper-catalysts was more selective towards the formation of $\mathrm{CO}_{2}$. For propane and methane oxidation on cobalt-catalysts, in addition to $\mathrm{CO}_{2}$, partially oxidised hydrocarbons, such as aldehydes and ketones, were also observed.

Considering the total metal content in the studied catalysts (Table 3), Table 5 shows the observed specific activity during the reduction of $\mathrm{NO}$ to $\mathrm{N}_{2}$ on $\left|\mathrm{Cu}_{x}\right|$ and $\left|\mathrm{Co}_{x}\right|\left[\mathrm{Si}_{\mathrm{y}} \mathrm{Al}\right]-$ MFI. As can be seen, the higher the $\mathrm{Cu}$ loading in the in the former catalysts the lower their specific activity. This behaviour might be attributed to the different metal content in the catalytic bed and to the different nature of the $\mathrm{Cu}^{2+}$ cations as was commented during the discussion of the TPR- $\mathrm{H}_{2}$ analyses. On the other hand, for a higher metal content in the Co-catalysts a slightly higher specific activity is observed. As can also be seen in Table 5, the amount of metallic oxide present in the samples increases with the metal content. The specific activity and TPR- $\mathrm{H}_{2}$ data of $\mathrm{Cu}$-catalysts can indicate that $\mathrm{CuO}$ species are practically not active, however $\mathrm{Co}_{3} \mathrm{O}_{4}$ species seem to favour the activity of Co-catalysts.

Table 5. Specific activity and metal oxide content observed for the $\left|\mathrm{Cu}_{\mathrm{x}}\right|$ and $\left|\mathrm{Co}_{\mathrm{x}}\right|\left[\mathrm{Si}_{\mathrm{y}} \mathrm{Al}\right]-\mathrm{MFI}$ catalysts

\begin{tabular}{|c|c|c|c|}
\hline \multirow[b]{2}{*}{ Sample } & \multicolumn{2}{|c|}{$\begin{array}{c}\text { Specific Activity } \\
\left.\text { (mols of } \mathrm{N}_{2} \text { formed).(mols of metal }\right)^{-1} \cdot \mathrm{h}^{-1}\end{array}$} & \multirow[b]{2}{*}{$\% \mathrm{M}_{\mathrm{X}} \mathrm{O}_{\mathrm{Y}}{ }^{\mathrm{c}}$} \\
\hline & $450^{\circ} \mathrm{C}$ & $500{ }^{\circ} \mathrm{C}$ & \\
\hline$\left|\mathrm{Cu}_{0.30}\right|\left[\mathrm{Si}_{12} \mathrm{Al}\right]-\mathrm{MFI}^{\mathrm{a}}$ & 8.3 & 9.4 & 0.17 \\
\hline$\left|\mathrm{Cu}_{0.49}\right|\left[\mathrm{Si}_{12} \mathrm{Al}\right]-\mathrm{MFI}^{\mathrm{a}}$ & 7.5 & 7.8 & 0.4 \\
\hline$\left|\mathrm{Co}_{0.29}\right|\left[\mathrm{Si}_{12} \mathrm{Al}\right]-\mathrm{MFI}^{\mathrm{b}}$ & 3.5 & 5.6 & 0 \\
\hline$\left|\mathrm{Co}_{0.58}\right|\left[\mathrm{Si}_{12} \mathrm{Al}\right]-\mathrm{MFI}^{\mathrm{b}}$ & 4.1 & 5.9 & 0.7 \\
\hline
\end{tabular}

In the presence of: ${ }^{a}$ propane and ${ }^{\mathrm{b}}$ methane. ${ }^{\mathrm{c}}$ Estimated massic percentage, considering $\mathrm{CuO}\left(\mathrm{Cu}\right.$-catalysts) and $\mathrm{Co}_{3} \mathrm{O}_{4}$ (Co-catalysts). The values were obtained from TPR data as is indicated in the text.

\section{CONCLUSIONS}

The synthesised $|\mathrm{Na}|$-zeolites presented MFI structure and it was observed that with the decrease in aluminium content their morphology changed from aggregates of small crystals to isolated or twinned hexagonal prisms. The species present in $\left|\mathrm{Cu}_{\mathrm{x}}\right|$ and $\left|\mathrm{Co}_{x}\right|\left[\mathrm{Si}_{\mathrm{y}} \mathrm{Al}\right]-\mathrm{MFI}$ catalysts were mostly $\mathrm{Cu}^{2+}$ and $\mathrm{Co}^{2+}$ cations, which are compensating the negative charge of the zeolite structure. In the catalysts with higher metal content it was also evidenced the presence of metal oxides, generated during the calcination of $\mathrm{Me}(\mathrm{OH})_{2}, \mathrm{Me}^{2+}(\mathrm{OH})^{-}$or $\mathrm{Me}\left(\mathrm{O}-\mathrm{CO}-\mathrm{CH}_{3}\right)_{2}$ species, which are formed during ion exchange.

In the reduction of NO the activity of the catalysts increased as the content of the charge-compensating $\mathrm{Cu}^{2+}$ and $\mathrm{Co}^{2+}$ species increased. $\left|\mathrm{Cu}_{\mathrm{x}}\right|\left[\mathrm{Si}_{\mathrm{y}} \mathrm{Al}\right]-\mathrm{MFI}$ catalysts were only active in the presence of propane and they showed higher activity at lower temperatures than the $\left|\mathrm{Co}_{\mathrm{x}}\right|\left[\mathrm{Si}_{\mathrm{y}} \mathrm{Al}\right]-\mathrm{MFI}$ catalysts, the latter being more active with methane.

It the oxidation of hydrocarbons the Co-based catalysts were less selective for the formation of $\mathrm{CO}_{2}$. For both type of studied catalysts it was verified that in detriment to the desired oxidation with $\mathrm{NO}$, occurs preferentially their oxidation with $\mathrm{O}_{2}$.

\section{REFERENCES}

1. Pârvulesku, V. I.; Grange, P.; Delmon, B.; Catal. Today 1998, 46, 233.

2. Rangel, M. C.; Carvalho, M. F. A.; Quim. Nova 2003, 26, 265.

3. Amiridis, M. D.; Zhang, T.; Farrauto, R. J.; Appl. Catal., B 1996, 10, 203.

4. Iwamoto, M.; Hamada, H.; Catal. Today 1991, 10, 57.

5. Beutel, T.; Sarkany, J.; Lei, G. D.; Yan, J. Y.; Sachtler, W. M. H.; J. Phys. Chem. 1996, 100, 845 .

6. Gómez, S. A.; Campero, A.; Marínez-Hermández, A.; Fuentes, G. A.; Appl. Catal., A 2000, 197, 157.

7. Tabata, T.; Kokitsu, M.; Okada, H.; Sabatino, L. M. F.; Catal. Today 1996, 27, 91.

8. Li, Y; Battavio, P. J.; Armor, J. N.; J. Catal. 1993, 142, 561.

9. Batista, M. S.; Ph. D. Thesis, Universidade Federal de São Carlos, Brasil, 2002.

10. Atkins, P.; Jones, L.; Chemical Principles, $2^{\text {nd }}$ ed., W. H. Freeman and Company: New York, 2001.

11. McCusker, L. B.; Liebau, F.; Engelhardt, G.; Pure Appl. Chem. 2001, 73, 381.

12. Treacy, M. M. J.; Higgins, J. B.; von Ballmoos, R.; Zeolites 1996, 16, 327.

13. Batista, M. S.; Master Thesis, Universidade Federal de São Carlos, Brasil, 1997.

14. Jahn, S. L.; Ph. D. Thesis, Universidade Federal de São Carlos, Brasil, 1987.

15. Torre-Abreu, T. C.; Henriques, C.; Ribeiro, F. R.; Delahay, G.; Ribeiro, M. F.; Catal. Today 1999, 54, 407.

16. Sullivan, J. A.; Cunningham, J.; Appl. Catal., B 1998, 15, 275.

17. Carniti, P.; Gervasini, A.; Modica, V. H.; Ravasio, N.; Appl. Catal., B 2000, 28,175 .

18. Minchev, C.; Köhn, R.; Tsonsheva, T.; Dimitrov, M.; Fröba, M.; Stud. Surf. Sci. Catal. 2001, 135, 253.

19. Martins, L.; Peguin, R. P. S.; Wallau, M.; Urquieta-González, E. A.; J. Braz. Chem. Soc. 2005, 16, 589.

20. Wang, X.; Chen, H. Y.; Sachtler, W. M. H.; Appl. Catal., B 2000, 26 , L227.

21. Cruz, R. S. da; Mascarenhas, A J. S.; Andrade, H. M. C.; Appl. Catal., B 1998, 18, 223.

22. Ohtsuka, H.; Tabata, T.; Okada, O.; Sabatino, L. M. F.; Belusi, G.; Catal. Today 1998, 42, 45.

23. Itho, Y.; Nishiyama, S.; Tsuruya, S.; Masai, M.; J. Phys. Chem. 1994, 98, 960.

24. Moretti, G.; Dossi, C.; Fusi, A.; Recchia, S.; Psaro, R.; Appl. Catal., B 1999, $20,67$.

25. Dossi, C.; Fusi, A.; Recchia, S.; Psaro, R.; Moretti, G.; Microporous Mesoporous Mater. 1999, 30, 165.

26. Fierro, G.; Eberhardt, M. A.; Houalla, M.; Hercules, D. M.; Hall, W. K.; J. Phys. Chem. 1996, 100, 8468.

27. Li, Y.; Amor, J. N.; Appl. Catal., B 1993, 2, 239.

28. Adelman, B. J.; Beutel, T.; Lei, G. D.; Sachtler, W. M. H.; J. Catal. 1996, $158,327$. 